\title{
Filed studies on some probiotics to minimize hazard effects of prevailing heavy metals contamination for
} improving immunity and growth performance of Oreochromis niloticus

\author{
Alla Zikaria Abu-Braka ${ }^{1}$, Mona Saad Zaki ${ }^{1}$, Hossam Hassan Abbas ${ }^{1}$, Noor El Deen Ahmed Ismail ${ }^{1}$, Riyad \\ Khalil'2, Mahmoud Tanekhy², Talat Saad ${ }^{2}$
}

${ }^{1}$ Department of Hydrobiology, Veterinary Division, National Research Center, Cairo, Egypt

${ }^{2}$ Department of Poultry \& Fish Diseases, Faculty of Veterinary Medicine, Alexandria University, Egypt

\section{Type of article: Original}

\begin{abstract}
Aim: The objective of the present study was to determine the effect of some types of probiotics to minimize the hazard effect of cadmium on Oreochromis niloticus (O. niloticus) and to determine the influence of probiotics on the growth performance and immune status of $\mathrm{O}$. niloticus.

Methods: Fish were divided into four groups, the first one was fed on a diet without any additives (control group), and the second group was fed on diet with the addition of 0.1 from $\left(\mathrm{LC}_{50}\right)$ of cadmium $32 \mathrm{ppm}$ in water. The third group was fed on a diet containing $1 \mathrm{gm} / \mathrm{kg}$ of Lactobacillus acidophilus. The fourth group was fed on a diet containing $1 \mathrm{gm} / \mathrm{kg}$ of $\mathrm{L}$. acidophilus with 0.1 addition from $\left(\mathrm{LC}_{50}\right)$ of cadmium $32 \mathrm{ppm}$.

Results: The experiment lasted about 60 days which resulted in an improvement in growth performance, with a decrease in the number of micronucleus formation in the group which received the probiotic. The group which was affected with cadmium showed decrease in the growth performance with increase in the number of micronucleus formation while the group which received probiotics and treated with cadmium had significant improvement in growth performance and decreased in the number of micronucleus formation.

Conclusions: Probiotics decrease cadmium pollution.

Keywords: Probiotic, L. acidophilus, Cadmium, Growth performance, Macronucleus
\end{abstract}

\section{Introduction}

Today, the contamination of freshwaters with a wide range of pollutants has become a matter of great concern over the last few decades. Heavy metals are natural trace components of the aquatic environment, but their levels have increased due to domestic, industrial, mining and agricultural activities (1). Discharge of heavy metals into a river or any aquatic environment can change both aquatic species diversity and ecosystems, due to their toxicity and accumulative behavior. Aquatic organisms such as fish and shellfishes accumulate metals to concentrations many times higher than present in water (2). They can take up metals concentrated at different levels in their different body organs. Cadmium concentration is higher in gills and visceral organs than musculature (3). Cadmium is an extremely toxic heavy metal which is widely used in mining, metallurgical operations, electroplating industries manufacturing of vinyl plastics, electrical contacts, and metallic and plastic pipes. Most aquatic organisms have the capability of concentrating metals by feeding and metabolic processes, which can lead to accumulation of high concentrations of metals in their tissues. Studies carried out on fish have shown that cadmium heavy metal may have toxic effects, altering physiological activities in tissue and blood parameters of fish. Several studies explained that exposure of Nile tilapia to different concentrations of cadmium at different durations resulted in several genotoxic changes as micronuclei formation (4). Therefore, it is important to monitor heavy metals in aquatic environments (water and fish) and try to find non-traditional methods to minimize the hazardous effect of the prevailing heavy metals. Previous reports have revealed that some lactobacilli, including Lactobacillus rhamnosus, L. plantarum, and L. brevis, can bind and remove heavy metals such as cadmium, lead, and copper in vitro (5). Besides the cadmium

\section{Corresponding author:}

Professor Dr. Mona Saad Zaki, Department of Hydrobiology, Veterinary Division, National Research Center, Cairo, Egypt. Tel: +201009551147, Email: drmonazaki@yahoo.com

Received: December 17, 2016, Accepted: March 25, 2017, Published: April 2017

iThenticate screening: March 25, 2017, English editing: April 02, 2017, Quality control: April 12, 2017

(C) 2017 The Authors. This is an open access article under the terms of the Creative Commons Attribution-NonCommercialNoDerivs License, which permits use and distribution in any medium, provided the original work is properly cited, the use is non-commercial and no modifications or adaptations are made. 
binding capacity, lactobacilli are also known to have anti oxidative properties in human tissue, which may be another important characteristic for cadmium toxicity protection (6). On the basis of these special functions, lactobacilli seem to have potency against cadmium toxicity. This hypothesis was also proposed in a recent review, but to our knowledge, very few studies on the protective effects of lactobacilli against cadmium toxicity have been carried out so far, and the mechanism of such protection has not been studied yet. Therefore, it is interesting to investigate whether some lactobacilli might play a role in the alleviation of acute cadmium toxicity (7).

\section{Material and Methods}

\subsection{Materials}

Apparently healthy $216 \mathrm{O}$. niloticus with an average body weight of 25 grams were obtained from a private fresh water fish farm in Kafr El Sheikh Governorate, Egypt. Fish were kept in full glass aquaria measuring (50X40X40 $\mathrm{cm}$ ) and maintained in aerated de-chlorinated fresh water at $22{ }^{\circ} \mathrm{C} \pm 2$ for 2 weeks before the experiment for fish acclimatization. The health status was examined throughout the acclimatization period. The physico-chemical characteristics of the water used for fish bioassay were determined according to the method for analysis of the heavy metals in the water which was carried out in accordance with the American Public Health Association (8) using Atomic Absorption Spectrophotometer. A basal diet was prepared; $30 \%$ crude protein, $3.7 \mathrm{Kcal} / \mathrm{g}$ of metabolizable energy, $3.4 \%$ fiber and $7.03 \%$ fat as well as vitamins and minerals in the form of dry pellets prepared in the lab of the hydrobiology department, NRC. The additives and probiotics were: 1) Lactobacillus acidophilus (Lacteol fort) of which each gram contained 10 billion cfu (colony forming unit), produced by Tenth of Ramadan for Pharmaceutical Industries and Diagnostic Reagents (Ramada), 2) Cadmium chloride obtained from the National Research Center.

\subsection{Experiment}

\subsubsection{Experiment for detection of $L C_{50}$ of cadmium}

Seventy-two fish were divided into 6 groups, each group having 12 fish. The experiment last for $96 \mathrm{hrs}$. The fish were fed on isocaloric $4320 \mathrm{Kcal} / \mathrm{Kg}$ and isonitrogenous diets with $32 \%$ crud protein. Different concentrations of cadmium chloride were added to each group; zero (control), 10, 20,30,40,50 mg/L) respectively, the mortality rate for each group was estimated daily.

\subsubsection{Probiotic and cadmium study}

Fish were fed for 8 weeks on isocaloric $4320 \mathrm{Kcal} / \mathrm{Kg}$ and isonitrogenous diets with $32 \%$ crude protein. L.acidophilus was incorporated in fish diets and fed to groups 3 and 4 . Then, $0.1 \mathrm{gm} \mathrm{LC}_{50}$ of cadmium chloride (32 $\mathrm{ppm}$ ) was added to the water of the aquaria of group 2 and 4. Each treatment or group has 3 replicates and each replicate had $12 \mathrm{O}$. niloticus (Table 1). The total number of fish was $144 \mathrm{O}$. niloticus.

Table1. Schematic design of experimental strategy

\begin{tabular}{|l|l|l|}
\hline Groups & Treatment (3 replicates per treatment) & $\begin{array}{l}\text { Number of } \\
\text { fish }\end{array}$ \\
\hline $\begin{array}{l}\text { G } 1 \\
\text { Control) }\end{array}$ & O. niloticus feed (basal diets) without any additive & 36 \\
\hline G 2 & O. niloticus treated with 0.1 (LC $\mathrm{LC}_{50}$ ) of cadmium 32ppm added to water & 36 \\
\hline G 3 & O. niloticus treated with $1 \mathrm{gm} / \mathrm{kg}$ of L. acidophilus & 36 \\
\hline G 4 & $\begin{array}{l}\text { O. niloticus treated with } 1 \mathrm{gm} / \mathrm{kg} \text { of L. acidophilus with } 0.1\left(\mathrm{LC}_{50}\right) \text { of cadmium }(32 \\
\text { ppm) added to water }\end{array}$ & 36 \\
\hline Total & Fish per replicate 12 & 144 \\
\hline
\end{tabular}

\subsection{Weigh performance and feed utilization parameters}

Fish were weighed at two-week intervals (to minimize the effect of handling. Fish were collected and placed in specific containers containing a known sufficient amount of water. The total weight was determined to the nearest gram, then the fish were immediately returned to their aquaria conditions and the feed amount was adjusted and corrected according to their new weight. The performance parameters included mean weight gain (WG), average daily gain (ADG), specific growth rate (RGR), feed conversion ratio (FCR). Average daily gain was calculated. Total weight gain was estimated and feed conversion ratio was evaluated. The micronucleus test (MN) was performed according to the methods of Grisolia and Cordeiro with some minor modifications (9). Briefly, liver and gill samples obtained from different treated groups were immediately smeared onto clean glass slides, air dried overnight, and then fixed in absolute methanol for 15minutes. Each slide was stained with $5 \%$ Giemsa solution for 20 minutes. At least 3,000 erythrocytes for each animal specimen were identified, counted and scored microscopically under $1,000 \mathrm{X}$ in an Axiophot 2 Carl Zeiss microscope. 


\section{Results}

\subsection{Determination of $L C_{50}$ of in $O$. niloticus}

Results of determination of $\mathrm{LC}_{50}$ of cadmium in in O. niloticus are summarized in Table 2. The obtained results showed that the $\mathrm{LC}_{50}$ and sublethal dose of cadmium were $32.92 \mathrm{mg} / \mathrm{L}$ and $10 \mathrm{mg} / \mathrm{L}$, respectively.

Table 2. $\mathrm{LC}_{50}$ of $L$. acidophilus on $O$. niloticus

\begin{tabular}{|l|l|l|l|l|l|l|}
\hline Concentration 0f cadmium (mg $\backslash \mathrm{L})$ & No. of fish & No. of dead fish & $\mathrm{a}$ & $\mathrm{b}$ & $\mathrm{Axb}$ & $(\mathrm{axb})$ \\
\hline 0 & 12 & 0 & 10 & & & \\
\hline & & & & 0.5 & 5 & 5 \\
\hline 10 & 12 & 1 & 10 & & & \\
\hline & & & & 2.5 & 25 & 25 \\
\hline & 12 & 4 & 10 & & & \\
\hline 30 & & & & 4.5 & 45 & 45 \\
\hline 40 & 12 & 5 & 10 & & & \\
\hline & & & & 5.5 & 55 & 55 \\
\hline 50 & 12 & 6 & 10 & & & \\
\hline & & & & 7.5 & 75 & 75 \\
\hline
\end{tabular}

\subsection{Effect of L.acidophilus on water quality}

Table 3 cleared that, the water quality parameters (dissolved oxygen, total ammonia, nitrite, nitrate, total alkalinity, hardness, salinity, chloride, iron level and cadmium level) differ significantly among different treatment groups ( $\mathrm{p}<0.01)$.

Table 3. Water quality in different experimental groups of $O$. niloticus.

\begin{tabular}{|l|l|l|l|l|}
\hline Groups & G1 (Control) & $\begin{array}{l}\text { G (Cadmium } \\
\text { only) }\end{array}$ & $\begin{array}{l}\text { G3 (Probiotic } \\
\text { only) }\end{array}$ & $\begin{array}{l}\text { G5 (Cadmium } \\
+ \text { Probiotic) }\end{array}$ \\
\hline Dissolved $\mathrm{O}_{2}(\mathrm{mg} / \mathrm{L})$ & $6.80 \pm 1.80$ & $6.20 \pm 1.16$ & $6.60 \pm 1.14$ & $6.50 \pm 1.15$ \\
\hline $\mathrm{PH}$ & $7.66 \pm 1.67$ & $7.84 \pm 1.14$ & $7.54 \pm 1.52$ & $7.47 \pm 1.14$ \\
\hline Total ammonia mg/L. & $0.028 \pm 0.002$ & $0.057 \pm 0.002$ & $0.035 \pm 0.001$ & $0.046 \pm 0.001$ \\
\hline Nitrite $\left(\mathrm{mg} / \mathrm{L}, \mathrm{No}_{2}-\mathrm{N}\right)$ & $0.022 \pm 0.001$ & $0.044 \pm 0.002$ & $0.028 \pm 0.002$ & $0.037 \pm 0.001$ \\
\hline Nitrate $\left(\mathrm{mg} / \mathrm{L}, \mathrm{No}_{3}-\mathrm{N}\right)$ & $0.32 \pm 0.01$ & $0.66 \pm 0.02$ & $0.37 \pm 0.001$ & $0.49 \pm 0.001$ \\
\hline Total alkalinity $(\mathrm{mg} / \mathrm{l})$ & $73.42 \pm 3.24$ & $85.18 \pm 1.58$ & $79.84 \pm 2.84$ & $74.49 \pm 2.17$ \\
\hline $\begin{array}{l}\text { Hardness }\left(\text { as } \mathrm{CaCO}_{3}\right) \\
\text { (mg/L) }\end{array}$ & $118.44 \pm 8.14$ & $137.41 \pm 4.13$ & $114.42 \pm 4.13$ & $118.52 \pm 8.12$ \\
\hline Salinity \% & $3 \pm 0.01$ & $3 \pm 0.02$ & $3 \pm 0.01$ & $3 \pm 0.02$ \\
\hline Chloride $\mathrm{mg} / \mathrm{L}$ & $0.02 \pm 0.001$ & $0.03 \pm 0.001$ & $0.02 \pm 0.001$ & $0.03 \pm 0.001$ \\
\hline Iron ppm mg/L & $0.11 \pm 0.01$ & $0.12 \pm 0.01$ & $0.10 \pm 0.01$ & $0.12 \pm 0.01$ \\
\hline Cadmium $\mathrm{mg} / \mathrm{L}$ & $0.003 \pm 0.0001$ & $0.039 \pm 0.001$ & $0.003 \pm 0.0001$ & $0.034 \pm 0.001$ \\
\hline
\end{tabular}

Means within the same row of different litters are significantly different at $\mathrm{p}<0.01$.

\subsection{Effect of lactobacillus acidophilus on growth parameters}

The initial; body weight, final body weight, total gain, daily weight gain, relative growth rate, initial fish number, final fish number and survival rate percentage differed significantly among different treatments $(\mathrm{p}<0.01)($ Table 4).The initial body weight results did not show any significant differences $(\mathrm{p}<0.05)$ among different treatment groups and the initial weight ranged from $24.8 \mathrm{~g}$ and $25.20 \mathrm{~g}$ for G1 and G2 treated groups while in G3 and G4, its level reached to 24.7 and 24.8 for the same groups, respectively. The final body weight ranged from 42.6 to 58.5 gm. for the G2 and G3 groups respectively, while in G1 and G4, its level reached to 51.2 to 49.50 gm., respectively. The total gain ranged from 17.40 to $33.8 \mathrm{gm}$. for G2 and G3 respectively, while in G1 and G4 groups, its level reached to 26.40 to $20.7 \mathrm{gm}$. for the previous groups, respectively. The daily weight gain ranged from 0.29 to 0.57 gm. for G2 and G3 respectively, while in G1 and G4, its level reached to 0.44 to $0.35 \mathrm{gm}$. for the previous groups, respectively. While, the relative growth rate level ranged from 69.048 to $136.842 \mathrm{gm}$. for G2 and G3 groups respectively, in G1 and G4 its level reached to 106.452 to $83.468 \mathrm{gm}$. for the previous groups, respectively. The number of initial fish was 12 fish in each group. While the final number of fish ranged from 9 to 12 in the groups 
that were treated (G2, G1 and G3), in G4 it reached to 11 fish. The survival rate percentage ranged from $75 \%$ to 100 $\%$ in $\mathrm{G} 2, \mathrm{G} 1$, and $\mathrm{G} 3$ respectively, while, in G4 it reached to $91.6 \%$.

Table 4. Growth parameters in $O$. Nilotic use fed on experimental $\boldsymbol{L}$. acidophilus incorporated diet after 60 days

\begin{tabular}{|l|l|l|l|l|l|l|l|l|}
\hline & IW & FW & TG & DWG & RGR \% & Initial N & Final N & SR \% \\
\hline $\begin{array}{l}\text { Control } \\
\text { (G) }\end{array}$ & $24.8 \pm \mathrm{A} 2.88$ & $51.2 \pm \mathrm{B} 2.55$ & $26.4 \pm \mathrm{B} 6.24$ & $0.44 \pm \mathrm{B} 0.022$ & $106.452 \pm \mathrm{B} 4.52$ & $12 \pm \mathrm{A} 1.20$ & $12 \pm \mathrm{A} 1.20$ & $100 \pm \mathrm{A} 2.55$ \\
\hline $\begin{array}{l}\text { Cadmium } \\
\text { (G) }\end{array}$ & $25.2 \pm \mathrm{A} 2.52$ & $42.6 \pm \mathrm{D} 2.66$ & $17.4 \pm \mathrm{D} 4.17$ & $0.29 \pm \mathrm{D} 0.01$ & $69.048 \pm \mathrm{D} 6.22$ & $12 \pm \mathrm{A} 1.33$ & $9 \pm \mathrm{C} 0.22$ & $75 \pm \mathrm{C} 3.77$ \\
\hline $\begin{array}{l}\text { Probiotic } \\
\text { (G) }\end{array}$ & $24.7 \pm \mathrm{A} 2.43$ & $58.5 \pm \mathrm{A} 2.22$ & $33.8 \pm \mathrm{A} 3.38$ & $0.57 \pm \mathrm{A} 0.03$ & $136.842 \pm \mathrm{A} 8.44$ & $12 \pm \mathrm{A} 1.22$ & $12 \pm \mathrm{A} 1.22$ & $100 \pm \mathrm{A} 2.55$ \\
\hline $\begin{array}{l}\text { Cadmium } \\
\text { and } \\
\text { Probiotic } \\
\text { (G) }\end{array}$ & $24.8 \pm \mathrm{A} 2.47$ & $49.5 \pm \mathrm{C} 4.55$ & $20.7 \pm \mathrm{C} 2.77$ & $0.35 \pm \mathrm{C} 0.02$ & $83.468 \pm \mathrm{C} 8.46$ & $12 \pm \mathrm{A} 1.23$ & $11 \pm \mathrm{B} 1.10$ & $91.6 \pm \mathrm{B} 3.55$ \\
\hline
\end{tabular}

$\mathrm{IW}=$ =Initial Weight, $\mathrm{FW}=$ final weight, $\mathrm{TG}=$ total body gain, $\mathrm{DWG}=$ daily weight gain

\subsection{Effect of lactobacillus acidophilus on micronucleus of fish}

There was a significant difference among the incidences of micronucleated polychromatic erythrocytes (MnPCEs) of Nile tilapia that were exposed to cadmium and were protected with probiotics (Table 5). There was a higher level of MnPCEs observed in gills than its incidences in the liver. In liver; the higher level of MnPCEs increased gradually toward the last week of the experiment, especially at week 8 and especially in the group that was treated with cadmium + standard diet and reached to 43, followed by its level in the same diet at week 6 of the experiment, as its level was 35, and in week 4, reached to 31 and in week 2, reached to 28. While, the lower level of MnPCEs was observed in the group that was treated with probiotics, as its level in week 8,6,4 and 2 reached to 9, 8, 5 and 6 for the same weeks respectively. Also, the addition of probiotics to the cadmium treated diet decreased the level of MnPCEs, as its levels in week 8, 6, 4 and 2 were 16,14, 13 and 14, for the same weeks, respectively.

Table 5. Micronucleated polychromatic erythrocytes (MnPCEs) of Nile tilapia exposed to Cadmium and protected with Probiotics and/or garlic.

\begin{tabular}{|l|l|l|l|l|}
\hline Time & Treatment & \multirow{2}{*}{ Conc.(mg/kg) } & \multicolumn{2}{l|}{ MnPCEs / 3000 PCEs } \\
\cline { 4 - 5 } & & & 2 weeks \\
\cline { 4 - 5 } & & Liver & Gills \\
\hline 2-Weeks & Normal control group & --- & $7 \pm 1.5 \mathrm{GH}$ & $8 \pm 1.40 \mathrm{G}$ \\
\cline { 2 - 5 } & Cadmium + Standard diet & & $28 \pm 2.8 \mathrm{D}$ & $31 \pm 4.55 \mathrm{C}$ \\
\cline { 2 - 5 } & Probiotics (lactobacillus) & $1 \mathrm{mg} / \mathrm{kg}$ diet & $6 \pm 0.50 \mathrm{H}$ & $8 \pm 1.50 \mathrm{G}$ \\
\cline { 2 - 5 } & Cadmium + Probiotic & & $14 \pm 1.40$ & $15 \pm 2.55 \mathrm{D}$ \\
\hline 4-Weeks & Normal control group & --- & $6 \pm 1.6 \mathrm{H}$ & $7 \pm 1.22 \mathrm{G}$ \\
\cline { 2 - 5 } & Cadmium + Standard diet & & $31 \pm 4.20 \mathrm{C}$ & $33 \pm 4.55 \mathrm{C}$ \\
\cline { 2 - 5 } & Probiotics (lactobacillus) & $1 \mathrm{mg} / \mathrm{kg}$ diet & $5 \pm 1.3 \mathrm{H}$ & $8 \pm 1.55 \mathrm{G}$ \\
\cline { 2 - 5 } & Cadmium + Probiotic & & $13 \pm 2.10 \mathrm{E}$ & $14 \pm 1.55 \mathrm{D}$ \\
\hline 6-Weeks & Normal control group & --- & $8 \pm 1.20$ & $8 \pm 1.22 \mathrm{G}$ \\
\cline { 2 - 5 } & Cadmium + Standard diet & & $35 \pm 5.3 \mathrm{~B}$ & $37 \pm 5.44 \mathrm{~B}$ \\
\cline { 2 - 5 } & Probiotics (lactobacillus) & $1 \mathrm{mg} / \mathrm{kg}$ diet & $8 \pm 1.20 \mathrm{~F}$ & $9 \pm 1.22 \mathrm{FG}$ \\
\cline { 2 - 5 } & Cadmium + Probiotic & & $14 \pm 1.20 \mathrm{E}$ & $16 \pm 3.15 \mathrm{D}$ \\
\hline 8-Weeks & Normal control group & --- & & \\
\cline { 2 - 5 } & Cadmium + Standard diet & & $43 \pm 4.44 \mathrm{~A}$ & $48 \pm 5.44 \mathrm{~A}$ \\
\cline { 2 - 5 } & Probiotics (lactobacillus) & $1 \mathrm{mg} / \mathrm{kg}$ diet & $9 \pm 1.22 \mathrm{~F}$ & $11 \pm 2.22 \mathrm{E}$ \\
\cline { 2 - 5 } & Cadmium + Probiotic & & $16 \pm 4.33 \mathrm{E}$ & $19 \pm 2.22 \mathrm{D}$ \\
\hline
\end{tabular}

Samples were collected every 2 weeks from treatment start; Means within the same column of different litters are significantly different at $(\mathrm{p}<0.01)$

In Gills; the level of micronucleated polychromatic erythrocytes (MnPCEs) increased gradually toward the last week of the experiment especially at week 8 and especially in the group that was treated with cadmium + standard diet and reached to 48 , followed by its level in the same diet at week 6 of the experiment, as its levels were 37, and in 
week 4 reached to 33 and in week 2 reached 31. While the lower level of MnPCEs was observed in the group that was treated with probiotics, as its levels in week $8,6,4$ and 2 reached to $11,9,8$ and 8 for the same weeks respectively. The addition of probiotics to the cadmium treated diet decreased the level of MnPCEs, as its levels in week 8, 6, 4 and 2 were 19,16, 14 and 15, for the same weeks, respectively. The results of MnPCEs of O. niloticus exposed to cadmium and protected with probiotics and/or garlic cleared that, the addition of probiotics causes a decrease in the level of MnPCEs, and its addition in cadmium toxicity causes a decrease in the level of cadmium toxicity with a decreasing level of MnPCEs.

\section{Discussion and conclusions}

In some areas of Egypt, especially those of Kafr El-Sheikh Governorate, fish farms are depending on agriculture drainage water mixed with industrial operations which consider the main source of different types of heavy metals pollution as well as the phosphate fertilizer which is considered the main source of cadmium in the environment (10). Both types are considered an important source of cadmium pollution affecting the growth rate, immunity, pathogenic infection, prevalence of parasitic diseases and infestation in cultured fish. Some trials were used to remove or decrease such metals from the water of fish farms such as chemical trials, physical and biological methods (Probiotic). Chemical and physical methods are highly costly and not effective. The world Health Organization (WHO) defined probiotic as live microorganisms non-pathogenic, non-toxigenic, fermentative bacteria which, when given balanced or adequate amount improves the health status of the host, and it can be used as a biological method for toxin degradation and removal of heavy metals (11). Lactobacillus and Bifidobacterium are the most commonly used probiotic. This method is very safe, inexpensive, can remove a wide range of pollutants, improve water quality and it doesn't change nutritional quality. Lobo et al. (12) mentioned that probiotic supplementation in fish aquaculture has significantly increased in the last decade due to its beneficial effect on fish performance. Our results on determination of $\mathrm{LC}_{50}$ in $\mathrm{O}$. niloticus, cleared that the $\mathrm{LC}_{50}$ and sublethal dose of cadmium were $32.92 \mathrm{mg} / \mathrm{L}$ and $10 \mathrm{mg} / \mathrm{L}$, respectively. Our results are very similar to those of Kaoud et al. (13), where they reported that the $\mathrm{LC}_{50}$ of cadmium for O. niloticus was $40.533 \mathrm{mg} / \mathrm{L}$. The results were higher than that of Garcia-Santoset al. (14) where they observed that the $\mathrm{LC}_{50}$ of cadmium in teleost fish were $14.8 \mathrm{mg} / \mathrm{L}$. Our results cleared that the addition of the probiotics to the fish diet improved the body weight, body weight gain, average mean daily gain, decreased mortality and improved livability and survival rate percentage. Also, the probiotics can improve the harmful effect of cadmium toxicity and pollution in the fish diet. The addition of probiotics to fish diet improved the final body weight and chronic toxicity by cadmium $\left(0.1\right.$ from $\left.\mathrm{LC}_{50}\right)$ decreased the final body gain. It is clear that the result obtained at which the probiotic treated group gives the higher final body gain about 58.5 gm and the cadmium treated group about $42.6 \mathrm{gm}$, while in the control and cadmium and probiotic treated groups, its level reached to 51.2 to $49.50 \mathrm{gm}$., respectively and these results are similar to those obtained by the WHO (11). The total gain ranged from 17.40 to $33.8 \mathrm{gm}$. for the cadmium and probiotic treated group respectively, while in the control and cadmium and probiotic treated groups its level reached to 26.40 to $20.7 \mathrm{gm}$. for the previous groups, respectively. The daily weight gain ranged from 0.29 to $0.57 \mathrm{gm}$. for the cadmium and probiotic treated group respectively, while in the control and cadmium and probiotic treated groups, its level reached to 0.44 to $0.35 \mathrm{gm}$. for the previous groups, respectively. While, the relative growth rate level ranged from 69.048 to $136.842 \mathrm{gm}$. for the cadmium and probiotic treated group respectively, in the control and cadmium and probiotic treated groups its level reached to 106.452 to $83.468 \mathrm{gm}$. for the previous groups, respectively. Similar results obtained by other research (15-19) where they observed a more significant improvement in the growth parameters of Nile tilapia (total body gain, feed conversion rate, protein efficiency ratio) in the group supplemented with the probiotic, than the control group which was not supplemented with any probiotic. Also, the best body weight gain and FCR values observed with probiotic-supplemented diets suggested that, the addition of probiotics improved feed utilization, in practical terms this means that probiotic use can improve feed efficiency rates which result in production cost reduction. Similar results have been reported for probiotic use by Lara-Flores et al. (20). These studies cleared that the addition of the 1. acidophilus probiotic to feed of Nile tilapia improves the survival rate. The survival rate percentage ranged from $75 \%$ to $100 \%$ in cadmium treated groups and the control groups, probiotic and cadmium treated groups, respectively, while, in the cadmium and probiotic treated group it reached to $91.6 \%$. All these results mean that the addition of the probiotics to different groups improves the survival rate of the fish with a decrease in the harmful effect of the pollution with heavy metals (cadmium) by making a complex with the cadmium which prevents or decreases its absorption. Similar results obtained by other researchers $(19,21,22)$ where they provide that addition of lactobacillus probiotic to Nile tilapia fish farm which contain cadmium pollution leads to improvement in the survival rate. Regarding the effect of lactobacillus acidophilus on micronucleus of fish, the effects of the mutations can either be silent throughout many generations or have a significant impact on the gene pool of a population. For this reason, there is increasing interest in the use of bio indicators to study the effects of aquatic pollutants at the 
genomic level (23). Our results cleared that, application of lactobacillus acidophilus to the feed of Nile tilapia gives good protection against cadmium toxicity which cleared from MnPCEs which study the toxic effect of cadmium on cellular DNA. The higher level of MnPCEs is observed in gills than its incidences in liver. Our results were in accordance with other studies $(4,24,25)$ that reported there was significant increase in the frequencies of micronucleus (MN) in erythrocytes of tilapia Spp and other fresh water fish exposed to cadmium for long periods in comparison with fish which were not exposed to any pollution.

\section{Acknowledgments:}

Nothing to acknowledge.

\section{Conflict of Interest:}

There is no conflict of interest to be declared.

\section{Authors' contributions:}

All authors contributed to this project and article equally. All authors read and approved the final manuscript.

\section{References:}

1) Kalay M, Canli $\mathrm{M}$. Elimination of essential $(\mathrm{Cu}$ and $\mathrm{Zn})$ and non-essential $(\mathrm{Cd}$ and $\mathrm{Pb})$ metals from tissues of a fresh water fish, Tilapia zillii. Tropical Journal of Zoology. 2000; 24: 429-36.

2) Olaifa FE, Olaifa AK, Adelaja AA, Owolabi AG. Heavy metal contamination of Clariasgarpinus from a lake and Fish farm in Ibadan, Nigeria. Afric $J$ of Biomed Res. 2004; 7: 145-8. doi: 10.4314/ajbr.v7i3.54185.

3) Khaled A. Heavy metal concentrations in certain tissues of five commercially important fishes from ElMex Bay, Al-Exandria, Egypt. Egyptian Journal of Aquatic Biology and Fisheries. 2004; 8(1): 51-64.

4) Ashmawy AA, Rashed MA, Atta AH, Ibrahim AG, Abdel-Gawad FK. Genotoxic Effect of Cadmium on NileTilapia (Oreochromis niloticus). International Journal of Scientific \& Engineering Research. 2015; 6(8).

5) Choudhury HT, Harvey WC, Thayer TF, Lockwood WM, Stiteler PE, Goodrum JM, et al. Real-time PCR. EnfermInfecc Microbiol Clin. 2004; 22(5): 299-304.

6) Teemu H, Seppo S, Jussi M, Raija T, Kalle L. Reversible surface binding of cadmium and lead by lactic acid and bifidobacteria. Int J Food Microbiol. 2008; 125(2): 170-5. doi: 10.1016/j.ijfoodmicro.2008.03.041. PMID: 18471917.

7) El Zokm GM, Okbah MA, Younis AM. Assessment of heavy metals pollution using AVS-SEM and fractionation techniques in Edku Lagoon sediments, Mediterranean Sea, Egypt. J Environ Sci Health A Tox Hazard Subst Environ Eng. 2015; 50(6): 571-84. doi: 10.1080/10934529.2015.994945. PMID: 25837560.

8) Joshi J, Sahu O. American Public Health Association. Standard Methods for the Examination for Water and Wastewater. 19th edition. Byrd Prepess Springfield; 1995.

9) Grisolia CK, Cordeiro CMT. Variability in micronucleus induction with different mutagens applied to several species of fish. Gen Mol Biol. 2000; 23(1): 235. doi: 10.1590/S1415-47572000000100041.

10) Dimari GA, Abdulrahman JC, Garba ST. Metals concentrations in tissues of Tilapia galli, Clariaslazera and Osteoglossidae caught from Alau Dam, Maiduguri, Borno State, Nigeria. American Journal of Environmental Sciences. 2008; 4(4): 373-9. doi: 10.3844/ajessp.2008.373.379.

11) W H O. Health and Nutritional Properties of Probiotics in Food including Powder Milk with Live Lactic Acid Bacteria. World Health Organization, Geneva. 2001.

12) Tapia-Paniagua S, Lobo C, Moreno-Ventas X, Banda IG, Moriñigo MA, Carmen Balebona M. Probiotic Supplementation Influences the Diversity of the Intestinal Microbiota During Early Stages of Farmed Senegalese Sole (Solea senegalensis, Kaup 1858). Marine Biotechnology. 2014; 16(6): 716-28. doi: 10.1007/s10126-014-9588-6.

13) Kaoud HA, Zaki MM, El-Dahshan AR, Saeid Sh, El Zorba HY. Amelioration the Toxic Effects of Cadmium-Exposure in Nile Tilapia (Oreochromis Niloticus) by using Lemnagibba L. Life Science Journal. 2011; 8(1): 185-95.

14) Garcia Santos S, Fontaínhas-Fernandes A, Wilson JM. Cadmium tolerance in the Nile tilapia (Oreochromis niloticus) following acute exposure: assessment of some ionoregulatory parameters. Environ Toxicol. 2006; 21(1): 33-46. doi: 10.1002/tox.20152. PMID: 16463259.

15) Marzouk MS, Mostafa MM, Mohamed NM. Evaluation of immunomodulatory effect of some probiotics on cultured oreochromis niloticus. 8th International Symposium on Tilapia in Aquaculture. 2008; 1043-58. 
16) Siliem NA. Rearing studies on Oreochromis niloticus to evavaluate bacillus subtilis potential in growth performance and some physiological parameters. Egypt J Aquat Biol \& Fish. 2008; 12(4): 1-11.

17) Hrnandez LLH, Barrera TC, Mejia GC, Mejia JC, Carmen MD, Dosta M, et al. Effects of the commercial probiotic Lactobacillus casei on the growth, protein content of skin mucus and stress resistance of juveniles of the Porthole livebearer Poecilopsisgracilis (Poecilidae). Aquaculture Nutrition. 2010; (16): 407-11. doi: 10.1111/j.1365-2095.2009.00679.x.

18) Al-Dohai MA, Hashim R, Aliyu Paiko M. Effects of the probiotic, Lactobacillus acidophilus, on the growth performance, haematology parameters and immunoglobulin concentration in African Catfish (Clariasgariepinus, Burchell 1822) fingerling. Aquaculture Research. 2009; 40(14): 1642-52. doi: 10.1111/j.1365-2109.2009.02265.x.

19) Ridha MT, Azad IS. Preliminary evaluation of growth performance and immune response of Nile tilapia Oreochromis niloticus supplemented with two putative probiotic bacteria. Aquaculture Research. 2012; 43(6): 843-52. doi:10.1111/j.1365-2109.2011.02899.x.

20) Lara-Flores M, Olvera-Novoa MA, Guzmán-Méndez BE, Lopez-Madrid W. Use of the bacteria Streptococcus faecium and Lactobacillus acidophilus, and the yeast Saccharomyces cerevisiae as growth promoters in Nile tilapia (Oreochromis niloticus). Aquaculture. 2003; 216(1-4): 193-201. doi: 10.1016/S0044-8486(02)00277-6.

21) Monachese M, Burton JP, Reid G. Bioremediation and tolerance of humans to heavy metals through microbial processes: a potential role for probiotics? Appl Environ Microbiol. 2012; 78(18): 6397-404. doi: 10.1128/AEM.01665-12. PMID: 22798364, PMCID: PMC3426676.

22) Ayoola SO, Ajani EK, Fashae OF. Effect of Probiotics (Lactobacillus and Bifidobacterium) on Growth Performance and Hematological Profile of Clarias gariepinus Juveniles. World Journal of Fish and Marine Sciences. 2013; 5(1): 1-8. doi: 10.5829/idosi.wjfms.2013.05.01.6582.

23) Russo C, Rocco L, Morescalchi MA, Stingo V. Assessment of environmental stress by the micronucleus test and the Comet assay on the genome of teleost populations from two natural environments. Ecotoxicol Environ Saf. 2004; 57: 168-74. doi: 10.1016/S0147-6513(03)00027-7. PMID: 14759663.

24) Mahrous KF, Hassan AM, Radwan HA, Mahmoud MA. Inhibition of cadmium- induced genotoxicity and histopathological changes in Nile tilapia fish by Egyptian and Tunisian montmorillonite clay. Ecotoxicol Environ Saf. 2015; 119: 140-7. doi: 10.1016/j.ecoenv.2015.04.054. PMID: 26001163.

25) Jindal R, Verma S. In vivo genotoxicity and cytotoxicity assessment of cadmium chloride in peripheral erythrocytes of Labeo rohita (Hamilton). Ecotoxicol Environ Saf. 2015; 118: 1-10. doi: 10.1016/j.ecoenv.2015.04.005. PMID: 25890049. 